\title{
Influence of Ribavirin on Mumps Virus Population Diversity
}

\author{
Mirna Jurković, Anamarija Slović, Dubravko Forčić, Jelena Ivančić-Jelečki $\mathbb{1}$, Tanja Košutić-Gulija and \\ Maja Jagušić *
}

check for updates

Citation: Jurković, M.; Slović, A.;

Forčić, D.; Ivančić-Jelečki, J.;

Košutić-Gulija, T.; Jagušić, M. Influence of Ribavirin on Mumps Virus Population Diversity. Viruses 2021, 13, 2535. https://doi.org/ $10.3390 /$ v13122535

Academic Editor: Craig E. Cameron

Received: 30 October 2021

Accepted: 12 December 2021

Published: 17 December 2021

Publisher's Note: MDPI stays neutral with regard to jurisdictional claims in published maps and institutional affiliations.

Copyright: (c) 2021 by the authors. Licensee MDPI, Basel, Switzerland. This article is an open access article distributed under the terms and conditions of the Creative Commons Attribution (CC BY) license (https:/ / creativecommons.org/licenses/by/ $4.0 /)$.
Centre for Research and Knowledge Transfer in Biotechnology, University of Zagreb, Rockefellerova 10, 10000 Zagreb, Croatia; mirna.jurkovic@unizg.hr (M.J.); aslovic@unizg.hr (A.S.); dforcic@unizg.hr (D.F.); jivancic@unizg.hr (J.I.-J.); tkgulija@unizg.hr (T.K.-G.)

* Correspondence: mjagusic@unizg.hr; Tel.: +385-1-6414-392

\begin{abstract}
Frequent mumps outbreaks in vaccinated populations and the occurrence of neurological complications (e.g., aseptic meningitis or encephalitis) in patients with mumps indicate the need for the development of more efficient vaccines as well as specific antiviral therapies. RNA viruses are genetically highly heterogeneous populations that exist on the edge of an error threshold, such that additional increases in mutational burden can lead to extinction of the virus population. Deliberate modulation of their natural mutation rate is being exploited as an antiviral strategy and a possibility for rational vaccine design. The aim of this study was to examine the ability of ribavirin, a broad-spectrum antiviral agent, to introduce mutations in the mumps virus (MuV) genome and to investigate if resistance develops during long-term in vitro exposure to ribavirin. An increase in $\mathrm{MuV}$ population heterogeneity in the presence of ribavirin has been observed after one passage in cell culture, as well as a bias toward C-to-U and G-to-A transitions, which have previously been defined as ribavirin-related. At higher ribavirin concentration, $\mathrm{MuV}$ loses its infectivity during serial passaging and does not recover. At low ribavirin concentration, serial passaging leads to a more significant increase in population diversity and a stronger bias towards ribavirin-related transitions, independently of viral strain or cell culture. In these conditions, the virus retains its initial growth capacity, without development of resistance at a whole-virus population level.
\end{abstract}

Keywords: mumps virus; mutagenesis; virus population diversity; genetic variability; ribavirin

\section{Introduction}

Mumps orthorubulavirus (MuV) is a nonsegmented, negative-sense (NNS) RNA virus, belonging to the genus Orthorubulavirus in the family Paramyxoviridae. It causes a respiratory infection, which, in most cases, naturally passes within two weeks. However, due to the highly neurotropic nature of this virus, aseptic meningitis and encephalitis arise in 1-10\% and $0.1 \%$ of mumps infections, respectively [1]. An approved antiviral treatment, which would be extremely beneficial in these cases, does not exist. Live-attenuated vaccines are used worldwide and have greatly helped to decrease the incidence rate of mumps. Still, epidemics frequently occur due to genetic differences between vaccine strains and currently circulating viral strains, as well as primary or secondary vaccine failure (reviewed in [2]). Therefore, there is an urgent need to develop more effective and safer $\mathrm{MuV}$ vaccines [3].

The $\mathrm{MuV}$ genome is a 15,384 nucleotides-long RNA containing seven transcription units that encode nine proteins: nucleo $(\mathrm{N}), \mathrm{V} /$ phospho/I $(\mathrm{V} / \mathrm{P} / \mathrm{I})$, matrix $(\mathrm{M})$, fusion $(\mathrm{F})$, small hydrophobic (SH), hemagglutinin-neuraminidase (HN) and large (L) protein [4]. The RNA genome of paramyxoviruses is packaged by the $\mathrm{N}$ protein into a nucleocapsid that acts as the template for genome replication and transcription by the RNA-dependent RNA polymerase (RdRp) complex, which consists of the L and P proteins [5]. The L protein has catalytic activity, while the $\mathrm{P}$ protein acts as a cofactor that keeps the nucleocapsid in close proximity to the L protein. Since there is no similar enzymatic activity present in the host cells, the RdRp complex represents an attractive target for drug develop- 
ment [6]. Structure-based drug design is, however, hampered by a lack of high-resolution RdRp crystal structures for many RNA viruses, including MuV, and their structural and functional predictions can be made based only on comparison with other related NNS RNA viruses. Regarding L gene, they share six conserved regions (CR-I-CR-VI) and five functional domains: RdRp, poly-ribonucleotidyltransferase (PRNTase), connecting (CD), methyltransferase (MTase), and the C-terminal domain (CTD) [5,7].

RdRp of RNA viruses lacks proofreading activity, thereby generating heterogenous viral populations-termed mutant swarms or quasispecies-in which viral variants cooperate during infection $[8,9]$. This genetic plasticity allows viruses to evolve and quickly adapt to changing environments. The intrinsic error rate (roughly $10^{-4}$ mutations per nucleotide copied), or fidelity of RdRp, determines the mutation rate for each virus and the range of genetic variation upon which natural selection can act [8]. Each virus population exists near the maximum mutation rate, called the error threshold, beyond which the quasispecies enters into error catastrophe, losing its genetic information [10].

In recent years, the genetic heterogeneity of viral populations has been exploited for the design and application of antiviral therapeutics and vaccines. Firstly, lethal mutagenesis is being explored as an antiviral approach for driving viral populations toward nonfunctionality through increasing the average mutation rate using mutagens [11,12]. Secondly, it has been demonstrated that the fidelity of RdRp can be manipulated to create less or more diverse viral populations than those that naturally exist, which can result in attenuated phenotype in vitro and in vivo (reviewed in [13]). This can be achieved either by site-directed mutagenesis if the residues involved in RdRp fidelity are known, or by exposing the virus to mutagens such as nucleoside analogs, which allows the selection of viral variants with increased [14-17] or decreased RdRp fidelity [18-21]. To our knowledge, so far, there are no data on whether the latter approach can be applied for vaccine design against $\mathrm{MuV}$ or to other members of the Paramyxoviridae family.

Ribavirin (RBV) is a synthetic nucleoside analog with broad-spectrum antiviral activity that has frequently been used both for the selection of viral variants with changed polymerase fidelity and for exploring the lethal mutagenesis phenomenon. As a guanosine analog, it can be misincorporated into the replicating genomes by RdRp, where it pairs equally well with cytosine $(\mathrm{C})$ and uracil $(\mathrm{U})$, thereby leading to $\mathrm{C}$-to- $\mathrm{U}$ and guanine (G)-to-adenine (A) transitions in the progeny genomes [22]. This leads to the induction of error catastrophe as a result of the accumulation of mutations in the viral genome. RBV is reported to have several other direct and indirect mechanisms of action that lead to the inhibition of viral RNA and protein synthesis, including the inhibition of host inosine monophosphate dehydrogenase (IMPDH) and subsequent depletion of GTP pool, the inhibition of viral mRNA polymerase, the inhibition of viral capping, immunomodulatory activity, and the enhanced induction of interferon-related genes (reviewed in [11,12]). Despite having adverse effects, RBV is still recommended (usually in combination with recently introduced directly acting antivirals) for treatment of genotype 1a and 4 hepatitis $\mathrm{C}$ virus (HCV) infections, cases of cirrhosis in genotype $3 \mathrm{HCV}$ infections, severe cases of hepatitis $\mathrm{E}$ virus infection, severe respiratory syncytial virus pneumonia, and haemorrhagic fevers such as Lassa- and Crimean-Congo-fever [23]. The research on clinical RBV resistance and implication of mutagenesis in vivo has brought conflicting results, and the mechanisms behind it are not fully elucidated. Several studies have identified specific polymorphisms in the NS5B polymerase region of viruses isolated from RBV-treated patients with HCV [24-26] or HEV [27], from which only few have been experimentally associated with RBV resistance. Nonetheless, RBV-resistant and sensitive variants recently isolated in the cell culture represent new tools to improve the efficacy of current mutagenic compounds and to identify new compounds with previously unknown antiviral mutagenic activity. Although the antiviral effect of RBV on $\mathrm{MuV}$ replication has been previously demonstrated [28-30], the molecular mechanism behind it has so far not been elucidated. 
In this study, we investigated RBV's effect on the genetic variability of $\mathrm{MuV}$ populations with two goals: (a) to explore if RBV has mutagenic activity against $\mathrm{MuV}$, and (b) to examine if resistance can emerge during in vitro exposure to RBV.

\section{Materials and Methods}

\subsection{Cells and Reagents}

Vero (African Green monkey kidney epithelium) and A549 (human adenocarcinoma) cell lines were obtained from the European Collection of Cell Culture (ECACC, UK Health Security Agency, Salisbury, UK). They were maintained in Minimum Essential Medium with Earle's salts (MEM) or Dulbecco's Minimum Essential Medium (DMEM) (both from Capricorn Scientific, Ebsdorfergrund, Germany), respectively, supplemented with 10\% foetal bovine serum (FBS) (PAN-Biotech, Aidenbach, Germany), penicillin/streptomycin and L-glutamine (both from Capricorn Scientific, Ebsdorfergrund, Germany) at $37^{\circ} \mathrm{C}$ and $5 \% \mathrm{CO}_{2}$.

The stock solution of RBV (MilliporeSigma, St. Louis, Missouri, USA) was prepared as a $10 \mathrm{mM}$ solution in water for injections, sterile-filtered through a $0.22 \mu \mathrm{m}$ filter, aliquoted and stored at $-20^{\circ} \mathrm{C}$. Working solutions of RBV were prepared in medium containing $2 \%$ FBS immediately before use.

\subsection{Viruses}

The MuV laboratory strain (MuVi-C, genotype $\mathrm{N}$ ) was isolated from the L-Zagreb vaccine (accession number AY685920) through several rounds of plaque purification in Vero cells. MuV strain ZgA/Cro69 (genotype D) was isolated from a child diagnosed with parotitis in 1969 in Zagreb in the amnion of embryonated chicken eggs as one of two viral variants [31]. ZgA/Cro69 virus was further passaged 15× in MRC-5 (normal human lung) cells. Viral titre was determined using a plaque assay, as described in Forcic et al. [32].

All infections were performed in medium containing $2 \% \mathrm{FBS}$, penicillin/streptomycin and L-glutamine at $35{ }^{\circ} \mathrm{C}$ and $5 \% \mathrm{CO}_{2}$.

\subsection{Cell Viability Assays}

Vero or A549 cells were seeded in 96-well plates at a concentration of 15,000 cells per well in $130 \mu \mathrm{L}$ of MEM containing $10 \%$ FBS or DMEM containing $10 \%$ FBS, respectively, and grown overnight. The next day, medium was replaced with $100 \mu \mathrm{L}$ of fresh control medium containing $2 \%$ FBS (untreated cells) or $100 \mu \mathrm{L}$ of 2 -fold serial dilutions of RBV in medium containing $2 \%$ FBS (starting from $1000 \mu \mathrm{M}$ ). Cell treatment for each RBV concentration was carried out in six replicates, and wells containing medium only were used as the control. Cells were incubated at $35^{\circ} \mathrm{C}$ and $5 \% \mathrm{CO}_{2}$ for 3 and 4 days for Vero cells and A549 cells, respectively. Next, the medium was replaced with $100 \mu \mathrm{L}$ of fresh medium containing MTT (3-(4,5-dimethylthiazol-2-yl)-2,5-diphenyltetrazolium bromide) reagent (MilliporeSigma, St. Louis, Missouri, USA) at a final concentration of $0.5 \mathrm{mg} / \mathrm{mL}$, and cells were further incubated for $4 \mathrm{~h}$ at $35^{\circ} \mathrm{C}$. The medium was aspirated, cells were then dissolved in $200 \mu \mathrm{L}$ of DMSO, resuspended, incubated for $5 \mathrm{~min}$ at room temperature, and absorbance was read at $570 \mathrm{~nm}$ (with reference wavelength of $690 \mathrm{~nm}$ ) using Multiskan Spectrum (Thermo Fisher Scientific, Waltham, MA, USA).

To distinguish viable and nonviable cells, noninfected cells were seeded and treated with RBV as described in Section 2.6. At indicated time points following treatment, cells were trypsinised and the number of viable cells was determined microscopically in a hemacytometer by trypan blue exclusion.

\subsection{Kinetics of Viral Replication}

Vero or A549 cells were seeded in T-flasks $\left(25 \mathrm{~cm}^{2}\right)$ at a concentration of $1.1 \times 10^{6}$ cells in $12 \mathrm{~mL}$ of MEM containing 10\% FBS or DMEM containing 10\% FBS, respectively, and grown overnight. The next day, cell layers were washed twice with phosphate-buffered saline (PBS) and cells were infected at the multiplicity of infection (MOI) indicated in the 
Results section. After $1 \mathrm{~h}$ of adsorption, the virus was removed, cells were washed twice with PBS, and medium containing $2 \%$ FBS was added. Cells were further incubated at $35^{\circ} \mathrm{C}$. From day 1 to day 6 after infection, an aliquot was taken from each flask, and stored at $-60^{\circ} \mathrm{C}$ or below until viral titre was determined.

\subsection{Effect of Cell Confluence on Viral Replication}

Vero or A549 cells were seeded in 12-well plates at concentrations that resulted in approximately $100 \%, 75 \%$ and $50 \%$ of cell confluence the next day. Specifically, Vero cells were seeded at concentrations of $1.3 \times 10^{5}, 1.7 \times 10^{5}$ and $2.1 \times 10^{5}$ cells per well in $1 \mathrm{~mL}$ of MEM containing 10\% FBS; A549 cells were seeded in $1.1 \times 10^{5}, 1.5 \times 10^{5}$ and $1.9 \times 10^{5}$ cells per well in $1 \mathrm{~mL}$ of DMEM containing 10\% FBS. Each concentration was seeded in triplicate. Cells were grown overnight and the medium was removed. Then, cells were washed twice with PBS and infected with viruses at the MOI indicated in the Results section. After $1 \mathrm{~h}$ of adsorption, the virus was removed, cells were washed twice with PBS, medium containing $2 \%$ FBS was added, and cells were further incubated at $35^{\circ} \mathrm{C}$. Supernatants were collected on day 3 (for Vero cells) or day 4 (for A549 cells) and kept at $-60^{\circ} \mathrm{C}$ or below until viral titre was determined.

\subsection{RBV Dose-Dependent Curves}

Vero or A549 cells were seeded in 12-well plates at a concentration of $1.7 \times 10^{5}$ cells per well in $1 \mathrm{~mL}$ of MEM containing 10\% FBS and $1.5 \times 10^{5}$ cells per well in $1 \mathrm{~mL}$ of DMEM containing $10 \%$ FBS, respectively. Cells were grown overnight; then, the medium was removed and $1 \mathrm{~mL}$ of RBV serially diluted in medium containing $2 \%$ FBS or medium only was added. Cell treatment for each RBV concentration was carried out in triplicate. Cells were incubated at $35{ }^{\circ} \mathrm{C}$ and $5 \% \mathrm{CO}_{2}$ for $2 \mathrm{~h}$, washed twice with PBS and infected with viruses at the MOI indicated in the Results section. After $1 \mathrm{~h}$ of adsorption, the virus was removed, cells were washed twice with PBS, $1 \mathrm{~mL}$ of RBV serially diluted in medium containing $2 \%$ FBS or medium only was added to cells, and they were further incubated at $35^{\circ} \mathrm{C}$. Supernatants were collected on day 3 (for Vero cells) or day 4 (for A549 cells) following infection and kept at $-60^{\circ} \mathrm{C}$ or below until viral titre was determined.

\subsection{Virus Passaging in the Presence of RBV}

Vero cells were seeded in 6-well plates at a concentration of $0.45 \times 10^{6}$ cells per well in $2 \mathrm{~mL}$ of MEM containing 10\% FBS. A549 cells were seeded in T-flasks $\left(25 \mathrm{~cm}^{2}\right)$ at a concentration of $1.1 \times 10^{6}$ cells in $12 \mathrm{~mL}$ of DMEM containing $10 \%$ FBS. Cells were incubated overnight; then, the medium was replaced with the same volume of RBV serially diluted in medium containing $2 \%$ FBS or medium only. Cells were incubated at $35{ }^{\circ} \mathrm{C}$ and $5 \% \mathrm{CO}_{2}$ for $2 \mathrm{~h}$, washed twice with PBS and infected with viruses at the MOI indicated in the Results section. After $1 \mathrm{~h}$ of adsorption, the virus was removed; cells were washed twice with PBS and further incubated at $35^{\circ} \mathrm{C}$ in the medium used for cell pretreatment. Viral titre was determined in the supernatants on day 3 (for Vero cells) or day 4 (for A549 cells) and the next passage was performed with the same MOI used for the first passage.

\subsection{Next-Generation Sequencing (NGS)}

Viral RNA was extracted from $400 \mu \mathrm{L}$ of cell culture supernatant using the Quick-RNA Viral Kit (Zymo Research, Irvine, CA, USA), following the manufacturer's recommendations. Isolated RNA was reverse-transcribed with Superscript III (Thermo Fisher Scientific, Waltham, Massachusetts, USA) and amplified using Phusion polymerase (New England Biolabs, Ipswich, MA, USA), according to the manufacturer's protocol. Primer sequences are shown in Table S1. Fragments were separated on 1\% agarose gels, excised, purified using Nucleospin Gel and a PCR Clean-up Kit (Macherey-Nagel, Dueren, Germany) and quantified with a QuantiFluor ${ }^{\circledR}$ ONE dsDNA System (Promega, Madison, WI, USA). Libraries were prepared using an Illumina DNA Prep kit (Illumina, San Diego, CA, USA) following the manufacturer's protocol. They were quality checked on a 2100 Bioanalyzer using a 
High Sensitivity DNA Kit (Agilent, Santa Clara, CA, USA). Libraries were pooled and sequenced on a MiniSeq Mid Output Kit ( $2 \times 150$ paired-end reads, Illumina, San Diego, CA, USA).

\subsection{Analysis of Mutational Burden in Viral Populations}

The quality of raw reads was assessed with FastQC v0.11.8 and subjected to adapter removal, trimming of bases below a Q-score of 30 , and removal of reads shorter than $75 \mathrm{bp}$ using BBDuk within the BBTools package. Paired-end reads were aligned to the reference sequence using Bowtie2 v2.4.2 [33]. Geneious Prime ${ }^{\circledR}$ 2019.2.3 software was then used for majority consensus calling, and reads were realigned to the newly constructed sequence with Bowtie2. Samtools v1.12 [34] was used for further processing of alignments, including filtering reads that had a maximum of two mismatches to the reference sequence. Data regarding the number of obtained reads before and after filtering, as well as mean coverage of alignment, are shown in Table S2. V-Phaser 2 [35] was used to estimate diversity within viral populations. Based on the method described in [36], viral variants present at less than $1 \%$ in each sequenced sample were excluded from further analysis using our in-house Python script, which also removes variants found in primer regions. Additionally, the script filters out variants not present in at least five forward and reverse reads. Shannon's entropy and nucleotide diversity (an average number of nucleotide differences between any two genomes in the sample) [37] were calculated as measurements of viral population diversity. NGS data are available from the NCBI Sequence Read Archive (SRA) database, BioProject ID PRJNA776123.

\subsection{Statistical Analysis}

All graphs were created using GraphPad Prism 9 (Prism Software); 50\% inhibitory concentration $\left(\mathrm{IC}_{50}\right)$ values were also calculated using this software. Significant differences among multiple groups were determined using one-way ANOVA and post hoc TukeyKramer tests for normally distributed data or Kruskal-Wallis one-way ANOVA when data were not normally distributed. Differences were considered significant for $p<0.05$.

\section{Results}

\subsection{MuV Replication in Vero and A549 Cells and Their Sensitivity to RBV}

To address the potential mutagenic action of RBV against $\mathrm{MuV}$, we have chosen two different viruses: $\mathrm{MuVi}-\mathrm{C}$, a plaque-purified variant obtained from the L-Zagreb vaccine, and $\mathrm{ZgA} / \mathrm{Cro69}$, derived from the wild-type virus by continuous passages in the cell culture. As the antiviral activity of RBV is observed through a decrease in viral titre following in vitro infection, we paired chosen $\mathrm{MuV}$ strains with substrates where they grow to high titres (Vero cells for MuVi-C; A549 cells for ZgA/Cro69).

When infection is carried out at approximately $75 \%$ cell confluence, these viruses reach titres higher than $6 \log \mathrm{PFU} / \mathrm{mL}$ on day three (when using Vero cells and strain $\mathrm{MuVi-C}$ ) or day four (when using A549 cells and strain ZgA/Cro69) (Figures 1 and S1). Therefore, in the infection experiments with MuVi-C and $\mathrm{ZgA} / \mathrm{Cro69}$, we decided to collect supernatants on day three and day four post infection, respectively. In addition, the lowest MOI was chosen in order to minimize the chance of defective viruses being generated, which can arise in mumps-infected cells with only a few passages [38].

We tested the sensitivity of Vero and A549 cells to RBV in our experimental setup (approximately 75\% cell confluence, incubation for 3 or 4 days, respectively) using the MTT cell viability assay. The results show that RBV decreased cell viability in a dosedependent manner with $\mathrm{IC}_{50}$ of $399 \mu \mathrm{M}$ for Vero cells (Figure S2a) and $423 \mu \mathrm{M}$ for A549 cells (Figure S2b). RBV concentrations higher than $15.62 \mu \mathrm{M}$ and $31.25 \mu \mathrm{M}$ led to statistically significant decreases in viability of Vero and A549 cells, respectively. In addition, no cytotoxic effect of RBV was observed in these cells when using the trypan blue exclusion method (data not shown) or by microscopical examination of cells' layers (Figure S2c,d). 


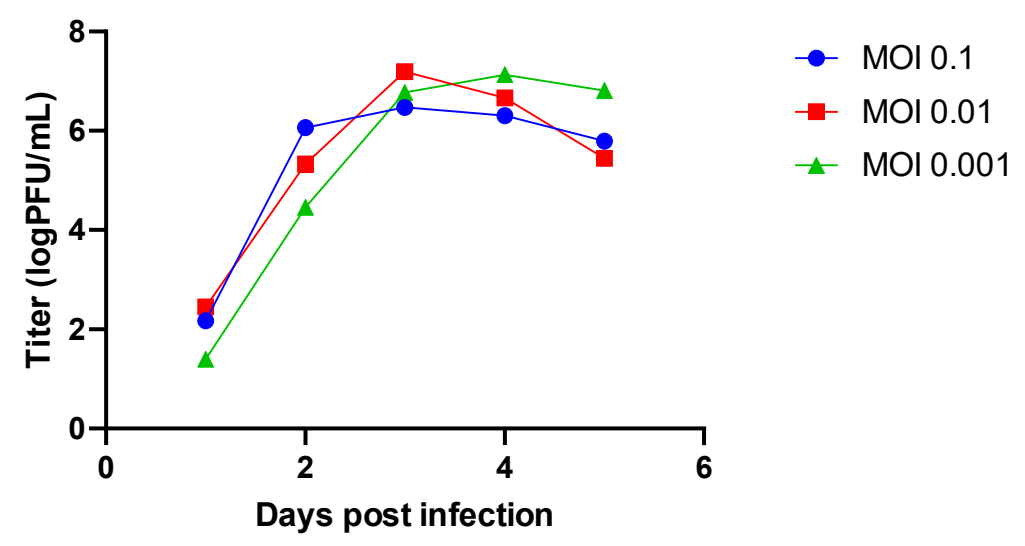

Figure 1. Mumps virus (MuV) replication in Vero cells. Vero cells in layers were infected with MuVi-C at different multiplicities of infection (MOIs). Supernatants were collected from day 1 to day 5 post infection. Titres in the supernatants were determined using a plaque assay.

\subsection{Antiviral Effect of RBV against $M u V$}

We examined the antiviral effect of RBV against $\mathrm{MuV}$ by comparing the viral titres in the supernatants of RBV-treated, infected cells versus untreated, infected cells. A549 and Vero cells were pretreated with two-fold serial dilutions of RBV in medium (in a range of 3.9 to $1000 \mu \mathrm{M}$ ) or medium only, infected with $\mathrm{MuV}$ and further incubated in the same medium used for pretreatment. A clear dose-dependent antiviral effect of RBV was observed for both viruses (Figures 2a and S3). Fifty percent effective dose (ED $\left.{ }_{50}\right)$ was estimated as $13.67 \mu \mathrm{M}(95 \%$ CI 9.526 to 17.82$)$ for MuVi-C (due to fewer RBV concentrations being used, it was not precisely determined for $\mathrm{ZgA} / \mathrm{Cro69)}$. A flow chart of experiments performed from this point forward is shown in Figure S4.

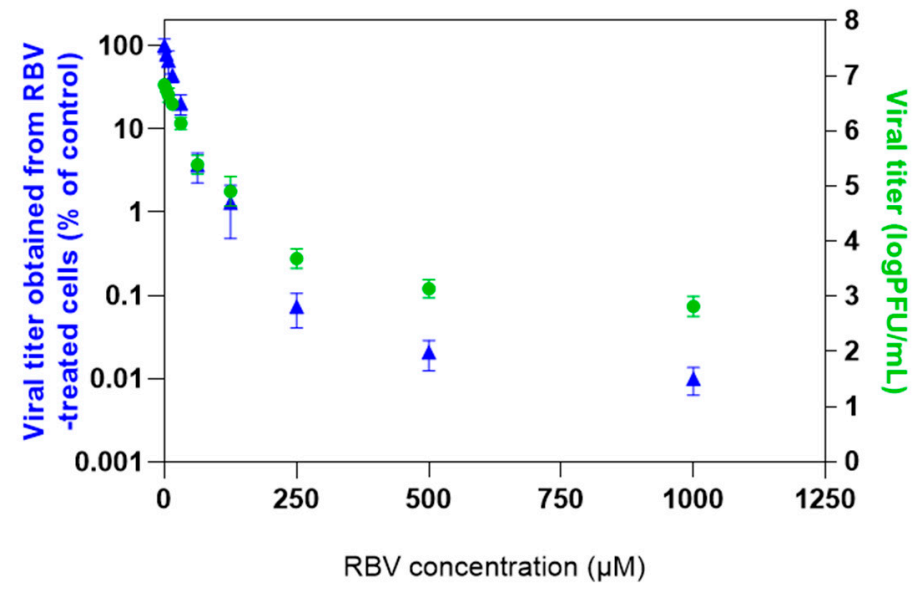

(a)

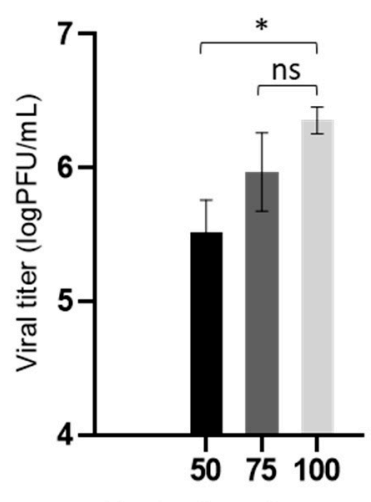

$\%$ of cell confluence

(b)

Figure 2. Dose-dependent antiviral effect of RBV against MuVi-C: (a) Vero cells were treated with different concentrations of RBV or mock-treated, infected with MuVi-C at MOI 0.001. Then, media with or without RBV were added for an additional $72 \mathrm{~h}$. Titres in supernatants were determined using the plaque assay; titres $(\log P F U / m L)$ are plotted on the right y axis, and the titre (number of plaques) of virus obtained from RBV-treated cells as a percentage of the virus titre obtained from untreated, control cells is given on the left y axis. (b) Vero cells were seeded to obtain $50 \%, 75 \%$ and $100 \%$ confluence on the day of infection, infected with MuVi-C at MOI 0.001. Supernatants were collected after $72 \mathrm{~h}$ and titres in supernatants were determined using the plaque assay. Mean and standard deviations are shown from 3 biological replicates. Statistical significance between groups was determined using Kruskal-Wallis one-way ANOVA ( ${ }^{*} p<0.05 ;$ ns, nonsignificant).

Next, we addressed the possibility that at RBV concentrations that negatively impact cell viability, a virus replication could have been impaired due to the lower number of cells 
susceptible to infection and not exclusively because of RBV's antiviral activity. Infection was performed in cell layers grown at approximately $100 \%, 75 \%$ and $50 \%$ confluence. Viral titres in A549 on day four post infection were not affected by the number of cells seeded for infection (Figure S5). Although viral titres on day three post infection were affected by the number of Vero cells available for infection (Figure $2 b$ ), this drop in viral titre was at least $500 \times$ smaller than the observed drop in titre when RBV was applied. For example, an RBV concentration of $250 \mu \mathrm{M}$ leads to an almost 50\% decrease in cell viability (Figure S2a) and causes $1423 \times$ less viral particles; in addition, a $50 \%$ difference in the number of cells only results in a 2.5-fold lower viral titre (Figure $2 b$ ). Although a contribution of decreased cell viability on RBV's antiviral effect for concentrations higher than $250 \mu \mathrm{M}$ cannot be estimated from this experiment, a small additional negative effect that higher RBV concentrations have on the cell viability would not be expected to significantly influence the viral titre.

Taken together, these results confirm RBV's antiviral activity, independent of strain used in our experimental system, and suggest that the number of cells available for infection makes only a minor contribution to the overall RBV's antiviral effect.

\subsection{RBV Effect on Genetic Diversity of MuV Populations after Only One Passage}

To estimate if RBV activity includes the induction of mutations in the MuV genome, $\mathrm{MuVi}-\mathrm{C}$ and $\mathrm{ZgA} / \mathrm{Cro} 69$ viruses passaged only once in the medium containing $250 \mu \mathrm{M}$ RBV or control medium, in two independent experiments, were sequenced using NGS. Due to the low viral titre of RBV-treated viruses, approximately two-thirds of the genome (extending from nucleotide 5255 for $\mathrm{MuVi}-\mathrm{C}$ or 4122 for $\mathrm{ZgA} / \mathrm{Cro} 69$ to the genome end) was successfully amplified for preparation of the library.

Except for nucleotide change T-to-C at position 6348 of $\mathrm{ZgA} / \mathrm{Cro69}$ viruses, which was already present at a high percentage in the parental sample, there were no changes in the consensus sequence of analysed samples. However, data analysis showed an increase in heterogeneity for both RBV-treated viruses in comparison to their respective controls or parental virus (Table 1, Figure 3).

In the case of MuVi-C viruses, $2-4 \times$ more heterogenous sites were found in RBVtreated viruses compared to their controls, as well as 1.3-2-fold higher Shannon's entropy. Variable nucleotide positions were not consistent between same samples from independent experiments with respect to the genomic location; only three positions were variable in both RBV-treated samples, while six of them were variable in both control samples.

For ZgA/Cro69 viruses, all analysed samples (parental, controls, and RBV-treated samples) shared several sites of higher variant frequency, reflecting the heterogenicity present in the parental viral sample (Figure 3). Approximately 45\% (in experiment 1 ) and $60 \%$ (in experiment 2 ) of low-frequency variable sites were found in the RBV-treated samples that were not detected in the parental nor in the control samples. On the other hand, only one heterogeneous position was present in both control samples, which did not occur in the RBV-treated or parental samples.

Next, the distribution of mutation types in our viruses was analysed. The only two mutation types that increased in percentage in RBV-treated viruses compared to their controls were C-to-U (all RBV-treated viruses) and G-to-A (all RBV-treated viruses, except for $\mathrm{MuVi}-\mathrm{C}$ from experiment 1 ), although without statistical significance (Table S4). These mutations have been reported as RBV-specific mutations for several other viruses [39-42] and they are presented together in our data (Table 1, Figure 3).

Together, these data indicate that RBV is able to cause MuV mutagenesis independently of strain or cell type used in our experimental system. The results further support the accumulation of RBV-specific G-to-A and C-to-U transitions. 
Table 1. Genetic characterization of RBV-treated $(250 \mu \mathrm{M})$ and control MuVi-C and ZgA/Cro69 viruses from the first passage in Vero and A549 cells, respectively.

\begin{tabular}{|c|c|c|c|c|c|c|c|c|c|}
\hline Virus & $\begin{array}{c}\text { Treatment } \\
\text { (Control or } \\
\text { RBV) }\end{array}$ & Passage & $\begin{array}{l}\text { Viral Titre } \\
(\log P F U / m L)\end{array}$ & $\begin{array}{c}\text { Total } \\
\text { Diversity } \\
\left(\times 10^{-4}\right)\end{array}$ & $\begin{array}{c}\text { Shannon's } \\
\text { Entropy } \\
\left(\times 10^{-4}\right)\end{array}$ & $\begin{array}{c}\text { Total no. of } \\
\text { Heteroge- } \\
\text { neous } \\
\text { Positions }\end{array}$ & $\begin{array}{c}\text { No. of } \\
\text { Muta- } \\
\text { tions } \\
\text { C-to-U }\end{array}$ & $\begin{array}{c}\text { No. of } \\
\text { Mutations } \\
\text { G-to-A }\end{array}$ & $\begin{array}{c}\text { \% of } \\
\text { Mutations } \\
\text { C-to-U } \\
+ \text { G-to-A }\end{array}$ \\
\hline \multirow{5}{*}{ MuVi-C } & - & 0 & 5.60 & 0.232 & 0.225 & 5 & 1 & 0 & 20 \\
\hline & control 1 & 1 & 6.61 & 0.982 & 0.855 & 17 & 3 & 1 & 24 \\
\hline & RBV 1 & 1 & 3.93 & 1.037 & 1.082 & 34 & 15 & 7 & 65 \\
\hline & control 2 & 1 & 6.93 & 1.257 & 0.927 & 12 & 2 & 2 & 33 \\
\hline & RBV 2 & 1 & 3.68 & 1.962 & 1.901 & 47 & 10 & 17 & 57 \\
\hline \multirow{5}{*}{ ZgA/Cro69 } & - & 0 & 5.34 & 1.837 & 1.447 & 23 & 5 & 1 & 26 \\
\hline & control 1 & 1 & 4.96 & 1.779 & 1.446 & 25 & 5 & 2 & 28 \\
\hline & RBV 1 & 1 & 3.41 & 2.177 & 1.850 & 40 & 9 & 8 & 43 \\
\hline & control 2 & 1 & 5.35 & 1.804 & 1.481 & 28 & 2 & 7 & 32 \\
\hline & RBV 2 & 1 & 2.80 & 2.533 & 2.151 & 49 & 17 & 9 & 53 \\
\hline
\end{tabular}

"-" in the Treatment column stands for parental virus; and 1 or 2 stands for independent experiments.
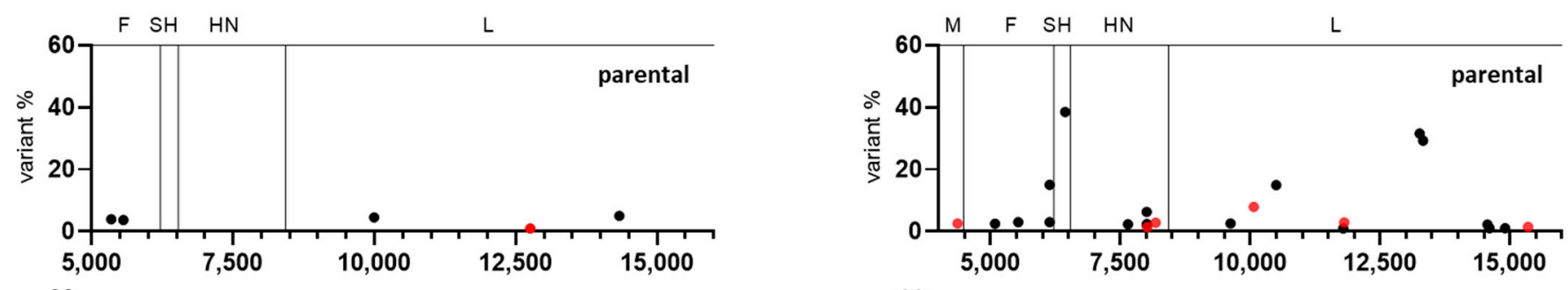

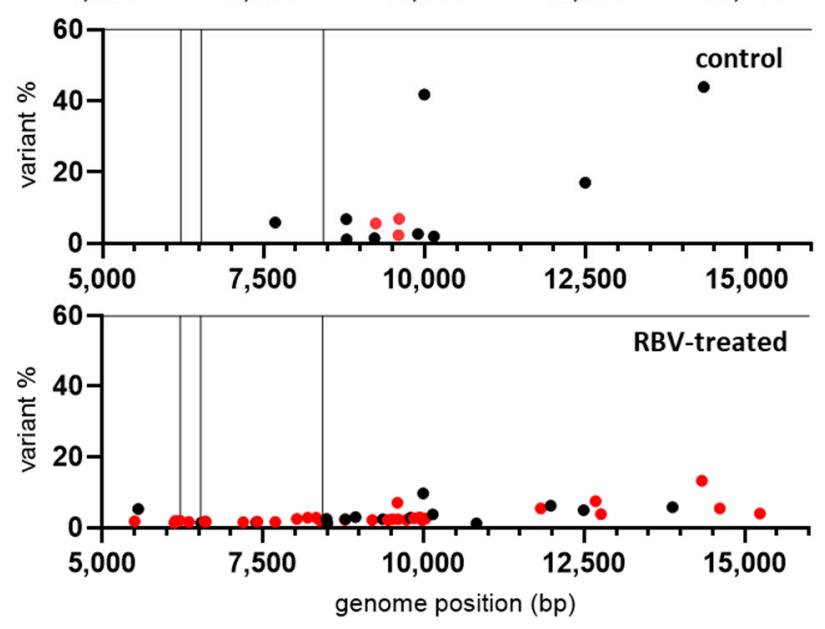

(a)
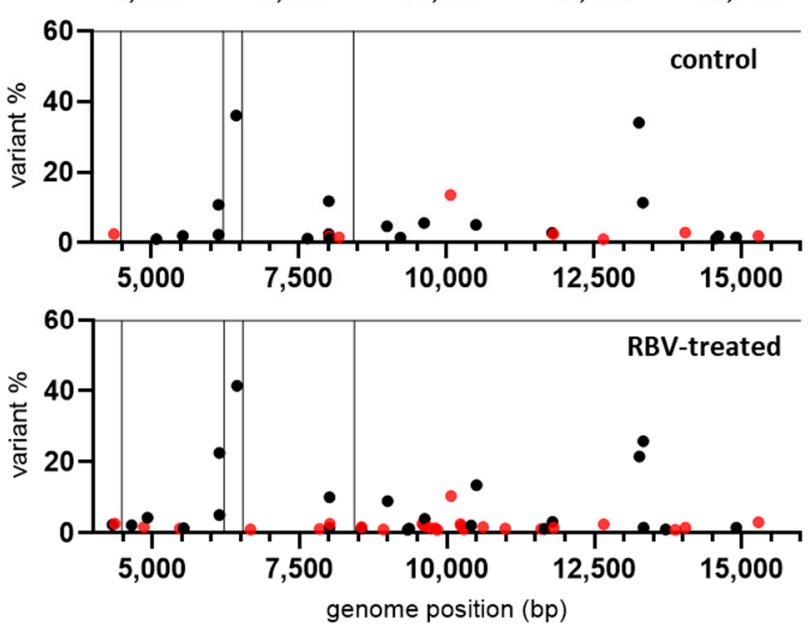

(b)

Figure 3. Variant frequency $(\%)$ in parental and RBV-treated $(250 \mu \mathrm{M})$ or control MuVi-C and ZgA/Cro69 viruses from the first passage in Vero and A549 cells, respectively, according to their location in the genome: (a) MuVi-C and (b) ZgA/Cro69. Corresponding genes are given at the top of the diagrams. RBV-specific mutations (G-to-A and C-to-U) are shown by red dots and all other mutation types by black dots. Only variants present at $>1 \%$ are shown.

\subsection{RBV Concentration Defines MuV Replication Outcome during Several Passages}

To examine if the observed antiviral activity of RBV can lead to virus extinction, we performed consecutive passages of MuVi-C in Vero cells in the absence or presence of 125, 250 or $500 \mu \mathrm{M}$ RBV (Figure 4). The first two RBV concentrations caused less than a $50 \%$ decrease in cell viability, and application of $500 \mu \mathrm{M}$ RBV resulted in a $54 \%$ decrease in cell viability (Figure S2a).

Results obtained from two independent experimental infections show that after the initial drop in virus titre using RBV concentrations of $125 \mu \mathrm{M}$, virus growth started to recover in the subsequent passages. 
When applying $250 \mu \mathrm{M}$ RBV in the first experiment, the virus had no detectable titre at passage 5. Still, plenty of plaques were observed when this virus was further passaged in the control medium, while they were not detected if it was passaged in the RBV-supplemented medium (data not shown). Furthermore, virus with no detectable titre was not revived following three additional blind passages in the control medium. On the other hand, the titre of the virus treated with $250 \mu \mathrm{M}$ RBV in the second experiment initially decreased and then increased again at the fifth passage.
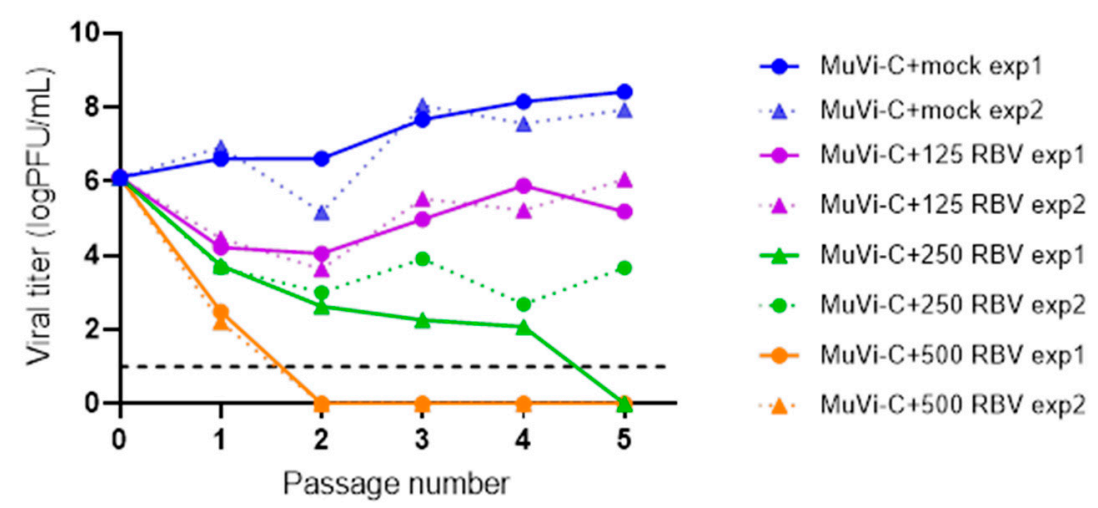

Figure 4. Passaging of MuVi-C in Vero cells treated with different concentrations of RBV. Vero cells were treated with different concentrations of RBV or mock-treated, infected with MuVi-C at MOI 0.001, and then, RBV or medium only were added for an additional $72 \mathrm{~h}$. Titres in supernatants were determined using the plaque assay, and they were further used for subsequent passage at MOI 0.001 in the same conditions. A cutoff value of the plaque assay is shown by a black, dashed line.

Finally, when using $500 \mu \mathrm{M}$ of RBV, the virus was extinguished at the second passage and was not revived following an additional three blind passages in the control medium.

These results demonstrate that the outcome of virus replication is strictly conditioned by the RBV concentration applied, and that there are marginal RBV concentrations $(250 \mu \mathrm{M})$ at which a permanent negative impact on virus fitness is a random event.

\subsection{Changes in MuV Population Diversity during Passaging in Sublethal Concentration of RBV}

To determine the effect of long-term passaging of $\mathrm{MuV}$ in the presence of RBV as well as a potential for selection of a resistance phenotype, our $\mathrm{MuV}$ strains were sequentially passaged in their respective substrates using either medium without RBV or medium supplemented with $62.5 \mu \mathrm{M} \mathrm{RBV}$, a concentration that does not drive $\mathrm{MuV}$ to extinction.

Following the initial drop in virus titre of $2.2 \log$ for $\mathrm{MuVi}-\mathrm{C}$ and $1.3 \log$ for $\mathrm{ZgA} / \mathrm{Cro69}$, the difference in titre between control and RBV-treated viruses was maintained throughout the passaging process (Figure S6). Control and RBV-treated viruses from passage eight were then sequenced in their full length. The heterogeneity of both RBV-treated viruses increased compared to respective control viruses from the same passage, as shown by three different diversity indices (Figure 5, Table 2). In the RBV-treated MuVi-C strain, it was more pronounced, being observed in $3 \times$ more heterogeneous sites, as well as having a 3.5 -fold higher nucleotide diversity and Shannon's entropy. In the RBV-treated ZgA/Cro69 strain, only a slight increase in the number of variants was observed $(1.2 \times$ more heterogeneous sites), in addition to 1.9-fold higher nucleotide diversity and a 1.7-fold increase in Shannon's entropy compared to the control. However, RBV-specific transitions (C-to-U and G-to-A) accumulated at a higher percentage in RBV-treated $\mathrm{ZgA} / \mathrm{Cro} 69$ virus $\left(84 \%, \mathrm{X}^{2}(1, \mathrm{~N}=99)\right.$ $=23.32, p<0.00001)$ than in RBV-treated MuVi-C virus $\left(64 \%, \mathrm{X}^{2}(1, \mathrm{~N}=127)=12.6\right.$, $p=0.000386$ ) compared to their respective controls or parental virus (Tables 2 and S5). This prompted us to perform additional passages (up to passage 21) of the $\mathrm{ZgA} / \mathrm{Cro69}$ strain to elucidate if longer exposure to RBV would result in a decrease in genetic variability and the emergence of RBV resistance. 
a) $\mathrm{ZgA} / \mathrm{Cro69}$

parental

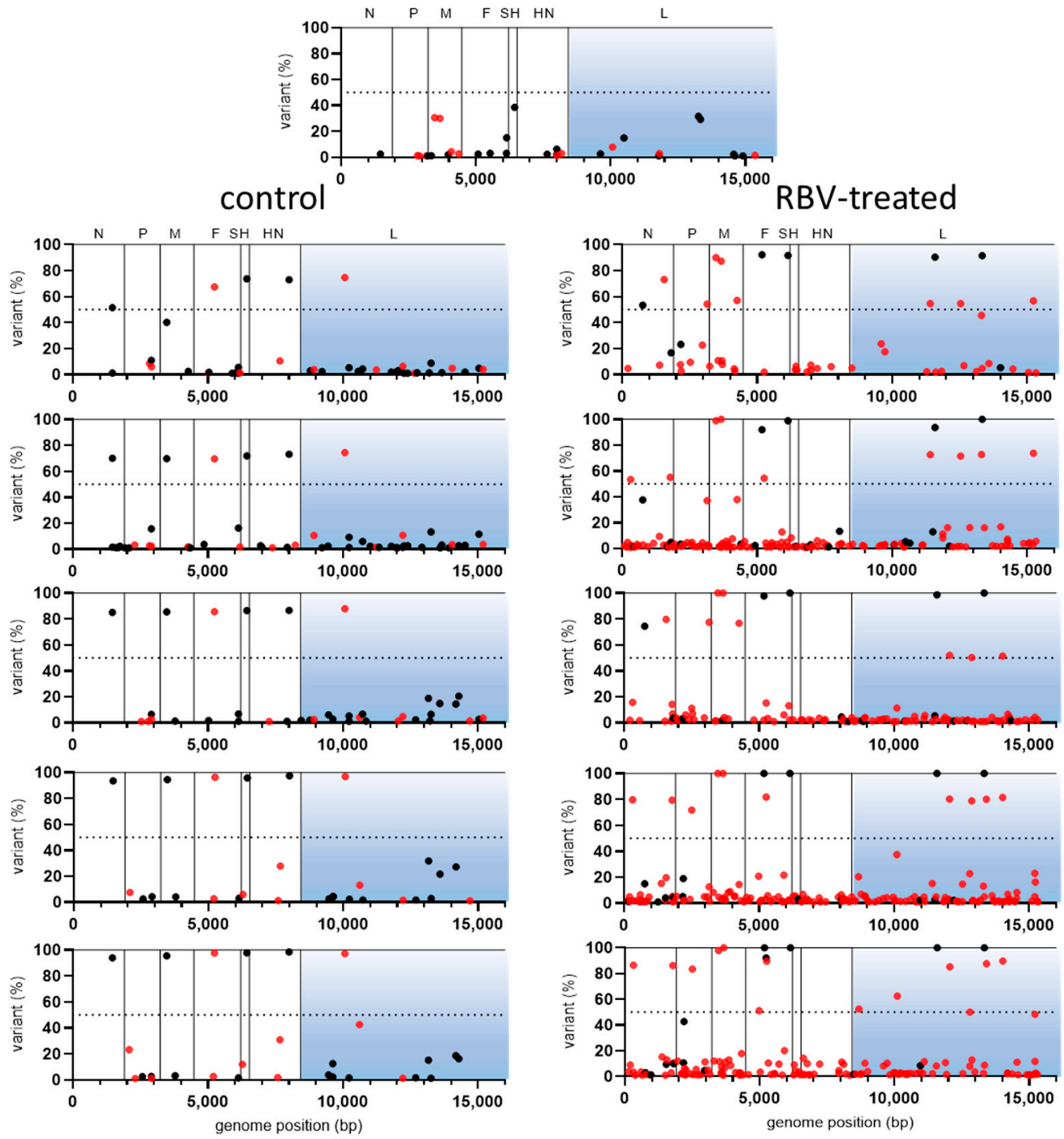

b) MuVi-C

parental

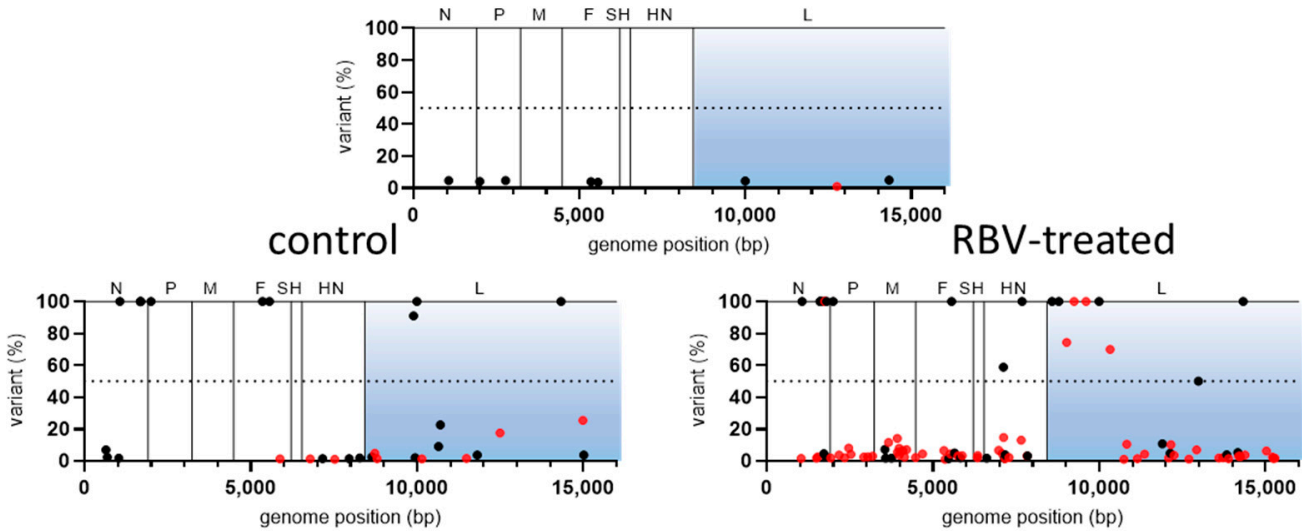

Figure 5. Variant frequency (\%) in parental and RBV-treated $(62.5 \mu \mathrm{M})$ or control (a) ZgA/Cro69 and (b) MuVi-C viruses from different passages in A549 and Vero cells, respectively, according to their location in the genome. RBV-specific mutations (C-to-U and G-to-A) are shown by red dots and all other mutation types by black dots. Dashed lines indicate a value of $50 \%$; changes present in values higher than $50 \%$ are consensus changes. The L gene, where resistance-/fidelity-related mutation/s are expected to emerge, is given in blue. Only variants present in $>1 \%$ are shown. 
Table 2. Genetic characterization of RBV-treated $(62.5 \mu \mathrm{M})$ and control ZgA/Cro69 and MuVi-C viruses from serial passages in Vero and A549 cells, respectively, based on full-length genome sequences.

\begin{tabular}{|c|c|c|c|c|c|c|c|c|c|}
\hline Virus & Treatment & $\begin{array}{c}\text { Passage } \\
\text { no. }\end{array}$ & $\begin{array}{l}\text { Viral Titre } \\
(\operatorname{logPFU/mL)}\end{array}$ & $\begin{array}{c}\text { Total } \\
\text { Diversity } \\
\left(\times 10^{-4}\right)\end{array}$ & $\begin{array}{c}\text { Shannon's } \\
\text { Entropy } \\
\left(\times 10^{-4}\right)\end{array}$ & $\begin{array}{l}\text { Total no. } \\
\text { of Hetero- } \\
\text { geneous } \\
\text { Positions }\end{array}$ & $\begin{array}{c}\text { No. of } \\
\text { Mutations } \\
\text { C-to-U }\end{array}$ & $\begin{array}{l}\text { No. of } \\
\text { Mutations } \\
\text { G-to-A }\end{array}$ & $\begin{array}{c}\% \text { of } \\
\text { Mutations } \\
\text { C-to-U + } \\
\text { G-to-A }\end{array}$ \\
\hline \multirow{11}{*}{ ZgA/Cro69 } & - & 0 & 5.34 & 2.581 & 2.012 & 33 & 8 & 4 & 36 \\
\hline & control & 8 & 6.45 & 3.299 & 2.617 & 44 & 8 & 7 & 34 \\
\hline & RBV & 8 & 6.35 & 6.247 & 4.561 & 51 & 17 & 26 & 84 \\
\hline & control & 11 & 8.01 & 3.918 & 3.178 & 56 & 6 & 8 & 25 \\
\hline & RBV & 11 & 6.02 & 9.596 & 8.019 & 158 & 78 & 61 & 86 \\
\hline & control & 14 & 8.56 & 2.723 & 2.249 & 38 & 3 & 9 & 32 \\
\hline & RBV & 14 & 6.31 & 7.622 & 6.196 & 122 & 55 & 50 & 85 \\
\hline & control & 17 & 8.14 & 2.201 & 1.783 & 28 & 4 & 6 & 36 \\
\hline & RBV & 17 & 5.52 & 10.243 & 8.747 & 158 & 79 & 67 & 91 \\
\hline & control & 21 & 7.49 & 2.260 & 1.764 & 28 & 5 & 6 & 39 \\
\hline & RBV & 21 & 6.51 & 10.639 & 8.709 & 150 & 72 & 64 & 91 \\
\hline \multirow{3}{*}{ MuVi-C } & - & 0 & 6.11 & 0.360 & 0.348 & 8 & 1 & 0 & 13 \\
\hline & control & 8 & 7.26 & 1.406 & 1.165 & 32 & 3 & 6 & 28 \\
\hline & RBV & 8 & 5.82 & 4.916 & 4.140 & 95 & 34 & 27 & 64 \\
\hline
\end{tabular}

"-" in the Treatment column stands for parental virus.

Control and RBV-treated ZgA/Cro69 viruses from passages 11, 14, 17 and 21 were sequenced in their full length. Contrary to our expectations, data showed that further passaging in RBV-supplemented medium led to an additional increase in heterogeneity resulting in a 4.7-fold higher genetic diversity of RBV-treated virus at passage 21 compared to the control virus $\left(10.64 \times 10^{-4}\right.$ and $2.26 \times 10^{-4}$, respectively (Figure 5, Table 2)). Similarly, the number of RBV-specific mutations (C-to-U and G-to-A) in RBV-treated virus increased with passage number and accounted for $91 \%$ of all mutations detected at passage 21 in comparison to only $39 \%$ in the control virus $\left(\left(X^{2}(1, N=183)=36.97, p<0.00001\right)\right.$, Figure 5, Table 2). Furthermore, genome analysis of RBV-treated virus revealed a total of 17 consensus changes at passage 21 that were not present in the control virus nor in the parental virus (Table S3). Eight consensus changes were located in the L gene; two were nonsynonymous mutations not specific for RBV $(11,584 \mathrm{G} \rightarrow \mathrm{T}$ and 13,332 $\mathrm{A} \rightarrow \mathrm{T}$, located in the PRNTase and CD domain, respectively), which were already present in the virus from passage eight, and three were RBV-specific nonsynonymous mutations $(12,051 \mathrm{G} \rightarrow \mathrm{A}$ in the PRNTase domain, $12,800 \mathrm{G} \rightarrow \mathrm{A}$ in the $\mathrm{CD}$ domain, and $14,018 \mathrm{G} \rightarrow \mathrm{A}$ in the MTase domain). In passaged RBV-treated $\mathrm{ZgA} / \mathrm{Cro69}$ virus, there were no changes in the $\mathrm{RdRp}$ domain of the L gene nor in the motifs crucial for the polymerase function GDN (in the RdRp domain), HR and GXXT (X denotes any residues in the CRV), and GXGXG (in the CRVI) [43]). In addition to $\mathrm{L}$ protein, $\mathrm{N}$ and $\mathrm{P}$ proteins also form an active RNP complex. In this context, two nonsynonymous RBV-specific changes were detected in the $\mathrm{N}$ gene $(315 \mathrm{G} \rightarrow \mathrm{A}$, and $1775 \mathrm{G} \rightarrow \mathrm{A})$, and one synonymous $(2503 \mathrm{C} \rightarrow \mathrm{T})$ in the $\mathrm{P}$ gene.

The resistance of treated and nontreated viral populations to higher concentrations of RBV $(125 \mu \mathrm{M}$ and $250 \mu \mathrm{M})$ was further compared in A549 cells. Results obtained for the viruses from the beginning (parental), midphase (passage 11) and end of the passaging process (passage 21) show that a comparable level of virus sensitivity to RBV was maintained throughout the experiment (Figure 6). These results suggest that resistance at a whole-virus population level did not develop in the $\mathrm{MuV}$ passaged in $62.5 \mu \mathrm{M}$ RBV. 


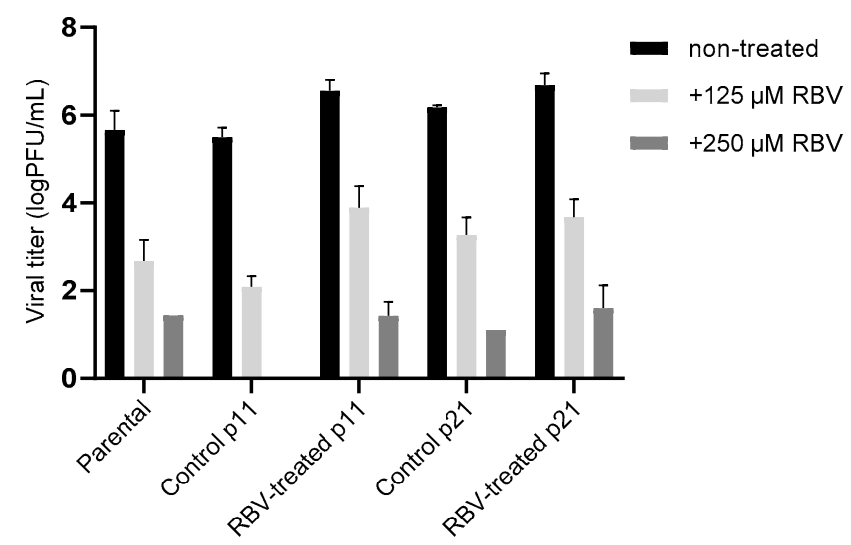

Figure 6. Resistance of passaged RBV-treated and control ZgA/Cro69 viruses to RBV. Parental, control, and RBV-treated viruses from passages 11 and 21 in A549 cells were tested for sensitivity to 125 or $250 \mu \mathrm{M}$ RBV in A549 cells. Titres in supernatants were determined using the plaque assay. Mean \pm standard deviation obtained from 3 biological replicates are shown. Statistical significance between groups was determined using Kruskal-Wallis one-way ANOVA. There were no significant differences between different samples treated with the same RBV concentration.

\section{Discussion}

There are several experimental conditions that must be fulfilled when setting up an optimal in vitro system for studying viral mutagenesis. Firstly, a combination of viral strain and cell line should facilitate viral replication to a substantial titre, as mutagen effects are subsequently determined through a decrease in viral titre. Secondly, the choice of MOI must not lead to an increase in defective interfering (DI) particles while causing peak titres in infection as early as possible so as to avoid prolonged and detrimental mutagen effects on cells. In the case of MuV, meeting those conditions is challenging because of the slowly replicating nature of the virus.

To estimate if RBV mutagenic activity applies to different MuV strains, we have chosen two viral strains that belong to different genotypes, and despite being extensively passaged in the cell culture, show neurovirulent phenotype (assayed in the conventional animal model for assessment of $\mathrm{MuV}$ neurovirulence-a newborn rat model, data not shown). We paired them with cell lines in which they replicate in high titres-Vero and A549. These cell lines have been reported as comparatively resistant to RBV [44,45]. It was further suggested that changing cell state (such as temperature for incubation, passage, or confluence) does not have any effect on RBV antiviral effect. In our experimental setup, these cells showed sensitivity to RBV with respect to cell viability, which decreased upon treatment ( $\mathrm{IC}_{50}$ dose of $399 \mu \mathrm{M}$ for Vero cells and $423 \mu \mathrm{M}$ for A549 cells). It should be noted that the same RBV concentrations had a lower impact on cell viability at earlier time points after infection (data not shown). In agreement with previous observations that RBV has antiproliferative rather than cytotoxic effects on Vero cells [28], we observed no cell cytotoxicity after RBV exposure. Due to the nature of $\mathrm{MuV}$ infection with respect to the time needed to obtain efficient cell infection, we opted to use subconfluent instead of confluent cells. Our results regarding RBV's effect on cell viability are in agreement with those obtained by Shigeta et al. [29] for growing Vero cells $(282 \mu \mathrm{M})$.

By using selected combinations of MuV strains and cell lines, we have confirmed through dose-dependent experiments that RBV's antiviral activity is independent of strain and cell type, with $\mathrm{ED}_{50}$ even lower than that obtained in similar measurements (37 to $149 \mu \mathrm{M})$ [29]. Although we have applied RBV concentrations that result in even more than a $50 \%$ decrease in cell viability, we have indirectly shown that reduced cell numbers in infection do not substantially affect viral titre. We therefore concluded that decreases in viral titre following RBV treatment are indeed the result of RBV action. In serial virus passages in the presence of $500 \mu \mathrm{M} \mathrm{RBV}$, virus titre was not detectable at passage two nor 
did its growth recover after additional passages in the control medium, suggesting that high RBV doses are able to extinguish virus population.

Leyssen et al. [46] have demonstrated that inhibition of IMPDH is a predominant mechanism by which RBV exerts its antiviral activity against paramyxoviruses, although RBV's effect on mutational burden in the viral genome was not investigated in their study. Our NGS data showed an increase in MuV population heterogeneity following only one virus passage in the cell culture, which is given by two different diversity indices (Shannon's entropy and the number of heterogeneous sites). On average, $2.95 \times$ more heterogeneous sites and a 1.65-fold higher Shannon's entropy were shown for one viral strain, and $1.67 \times$ more heterogeneous sites and a 1.36-fold higher Shannon's entropy for another. Importantly, an accumulation of RBV-specific mutations (C-to-U and G-to-A) was demonstrated for both viruses. A lack of insight into the contribution of an increase in heterogeneity and/or RBV-specific mutations to the loss of infectivity seen in passages of MuVs in the presence of 250 or $500 \mu \mathrm{M} \mathrm{RBV}$, due to inability to sequence a low titre viral samples, is a shortcoming of our study.

Depending on the virus, 5-15 passages are usually necessary to select for a fidelityrelated resistant phenotype, which is frequently indicated by titre equalization between viruses passaged in mutagen-containing medium and control medium [45]. The MOI used in our study was 5 to 50 times lower than MOIs previously shown to result in MuV DI emergence [38]. Since the resistant mutant is expected to initially exist in the population at a low frequency, we chose not to further decrease the inoculum population size to prevent the chance of losing these emerging variants. However, contrary to observations made for many other RNA viruses that show the emergence and accumulation of resistant variants following serial passages in sublethal RBV concentrations [14,16,17], we have shown that, in a course of 21 passages with $62.5 \mu \mathrm{M}$ RBV, MuV does not select for resistance. Deep-sequencing analysis showed that original viral heterogeneity increases with passage number for RBV-treated viruses, while it remains approximately the same for the control viruses (Table 2). The majority of observed substitutions detected in the RBV-treated virus were mutagen-related (C-to-U and G-to-A transitions accounted for $>90 \%$ of all observed substitutions).

A 1.5-2-fold difference in genetic diversity has previously been observed between viral populations possessing a natural mutation rate and those with changed replication fidelity for various RNA viruses [13]. In our study, a 4.7-fold higher genetic diversity of RBV-treated virus compared with the control virus was obtained at passage 21 without a change in RBV resistance. The fact that 150 heterogeneous positions were found in RBV-treated virus at the end of the passaging process shows that $\mathrm{MuV}$ is able to support high mutational burden within its genome. We consider the observed mutational increase significant, as by using the same sequencing methodology, only up to 50 heterogeneous positions were detected in populations of L-Zagreb vaccine samples from different manufacturing steps (unpublished data). Further investigation is needed to elucidate if the observed increase in heterogeneity is related to the slight drop in virus titre, or dependent on other direct or indirect RBV's effect on viral life cycle or cell metabolism, or both.

Regarding mutagen resistance, our results do not preclude the possibility that there are resistant variants present at a low level within RBV-treated MuV populations or that their phenotypic effect is masked by the impact of mutations elsewhere in the genome.

In addition, exposing $\mathrm{MuV}$ to a higher RBV concentration through serial passages might result in the occurrence of a resistant phenotype. Supporting this is our observation that an RBV concentration of $250 \mu \mathrm{M}$ led to virus extinction in one experiment (the virus was not recovered following several blind passages in the control medium), but in the second experiment, the virus was recovered after a significant initial drop in titre. Considering these results in combination with results obtained from the consecutive passages in a lower concentration of RBV $(62.5 \mu \mathrm{M})$, a higher selective pressure is possibly needed to cause mutagen-resistant variant occurrence, which would become dominant in the population. 
It seems that an RBV concentration of $250 \mu \mathrm{M}$ is at the boundary of pressure at which $\mathrm{MuV}$ can undergo.

This virus-mutagen interplay should be further investigated, as there are no specific, clinically approved treatments for mumps. Except for RBV [28-30], MuV antiviral activity has previously been investigated for several compounds of similar chemical structure (nucleoside analogues) including GS-5734 [47], favipiravir [48], 4'-azidocytidine [49], EICAR [46] and TJ13025 [29]. None of these studies have estimated whether the antiviral activity of these compounds involves an increase in mutagenic burden in the MuV genome. Thus, the lethal mutagenesis phenomenon is a promising future research direction for the design or application of mumps antivirals. The application of such antivirals would be beneficial in cases of serious neurological disease consequences such as meningitis or encephalitis [50-53], which can increase in number in regions without vaccination programs, in cases of large outbreaks, or in individuals who are unvaccinated due to a weakened immunological status.

\section{Conclusions}

The results of this study, obtained by using two combinations of cells and viruses, demonstrate that RBV increases the heterogeneity of viral populations and predominantly induces C-to- $\mathrm{U}$ and G-to-A transitions in the $\mathrm{MuV}$ genome. Even though $\mathrm{MuV}$ is sensitive to RBV, it can readily withstand sublethal concentrations of this mutagen without emergence of a resistance at a whole-virus population level.

Supplementary Materials: The following are available online at https:/ / www.mdpi.com/article/10.339 0/v13122535/s1, Figure S1. MuV replication in A549 cells; Figure S2. RBV effect on Vero and A549 cells; Figure S3. Dose-dependent antiviral effect of RBV against ZgA/Cro69; Figure S4. A flow chart of performed experiments; Figure S5. Effect of confluence of A549 cells on viral titre; Figure S6. Passaging of MuVi-C and ZgA/Cro69 viruses in Vero and A549 cells, respectively, treated with $62.5 \mu \mathrm{M}$ RBV; Table S1. List of primers used for amplification of PCR fragments for NGS library preparation; Table S2. NGS data description; Table S3. Changes in the consensus sequence (based on full-length genome sequences) during long-term passaging of RBV-treated (62.5 $\mu \mathrm{M}) \mathrm{ZgA} / \mathrm{Cro69}$ virus that are not present as consensus in the controls nor in the parental virus; Table S4. Percentage of each mutation type occurring in control and RBV-treated $(250 \mu \mathrm{M}) \mathrm{MuVi}-\mathrm{C}$ and ZgA/Cro69 viruses from the first passage; Table S5. Percentage of each mutation type occurring in control and RBV-treated $(62.5 \mu \mathrm{M}) \mathrm{MuVi}-\mathrm{C}$ and $\mathrm{ZgA} / \mathrm{Cro69}$ viruses from passages 8 and 21.

Author Contributions: Conceptualization, M.J. (Maja Jagušić), and M.J. (Mirna Jurković); methodology, all authors; analysis, A.S., M.J. (Maja Jagušić), M.J (Mirna Jurković), and J.I.-J.; investigation, A.S., T.K.-G., J.I.-J., M.J. (Maja Jagušić), and M.J. (Mirna Jurković); resources, D.F.; data curation, A.S., M.J. (Maja Jagušić), and M.J (Mirna Jurković); writing-original draft preparation, M.J. (Maja Jagušić), and M.J. (Mirna Jurković); writing-review and editing, all authors; supervision, D.F, and J.I.-J.; funding acquisition, D.F. All authors have read and agreed to the published version of the manuscript.

Funding: This research was funded by "Strengthening the capacity of CerVirVac for research in virus immunology and vaccinology", KK.01.1.1.01.0006, awarded to the Scientific Centre of Excellence for Virus Immunology and Vaccines and cofinanced by the European Regional Development Fund.

Institutional Review Board Statement: Not applicable.

Informed Consent Statement: Not applicable.

Data Availability Statement: Data are contained within the article and supplementary material. Sequencing results were deposited in the NCBI SRA database (https:/ / www.ncbi.nlm.nih.gov/sra, accessed on 16/12/2021) BioProject ID PRJNA776123.

Acknowledgments: Authors wish to thank Renata Jug for her technical assistance.

Conflicts of Interest: The authors declare no conflict of interest. The funders had no role in the design of the study; in the collection, analyses, or interpretation of data; in the writing of the manuscript, or in the decision to publish the results. 


\section{References}

1. Hviid, A.; Rubin, S.; Mühlemann, K. Mumps. Lancet 2008, 371, 932-944. [CrossRef]

2. Peltola, H.; Kulkarni, P.S.; Kapre, S.V.; Paunio, M.; Jadhav, S.S.; Dhere, R.M. Mumps outbreaks in Canada and the United States: Time for new thinking on mumps vaccines. Clin. Infect. Dis. 2007, 45, 459-466. [CrossRef]

3. May, M.; Rieder, C.A.; Rowe, R.J. Emergent lineages of mumps virus suggest the need for a polyvalent vaccine. Int. J. Infect. Dis. 2018, 66, 1-4. [CrossRef]

4. Elango, N.; Varsanyi, T.M.; Kovamees, J.; Norrby, E. Molecular cloning and characterization of six genes, determination of gene order and intergenic sequences and leader sequence of mumps virus. J. Gen. Virol. 1988, 69, 2893-2900. [CrossRef]

5. Abdella, R.; Aggarwal, M.; Okura, T.; Lamb, R.A.; He, Y. Structure of a paramyxovirus polymerase complex reveals a unique methyltransferase-CTD conformation. Proc. Natl. Acad. Sci. USA 2020, 117, 4931-4941. [CrossRef]

6. Cox, R.; Plemper, R.K. The paramyxovirus polymerase complex as a target for next-generation anti-paramyxovirus therapeutics. Front. Microbiol. 2015, 6, 459. [CrossRef]

7. Liang, B.; Li, Z.; Jenni, S.; Rahmeh, A.A.; Morin, B.M.; Grant, T.; Grigorieff, N.; Harrison, S.C.; Whelan, S.P.J. Structure of the L Protein of Vesicular Stomatitis Virus from Electron Cryomicroscopy. Cell 2015, 162, 314-327. [CrossRef]

8. Lauring, A.S.; Andino, R. Quasispecies theory and the behavior of RNA viruses. PLoS Pathog. 2010, 6, e1001005. [CrossRef]

9. Novella, I.S.; Presloid, J.B.; Taylor, R.T. RNA replication errors and the evolution of virus pathogenicity and virulence. Curr. Opin. Virol. 2014, 9, 143-147. [CrossRef]

10. Tejero, H.; Marín, A.; Montero, F. The relationship between the error catastrophe, survival of the flattest, and natural selection. BMC Evol. Biol. 2011, 11, 2. [CrossRef]

11. Graci, J.D.; Cameron, C.E. Mechanisms of action of ribavirin against distinct viruses. Rev. Med. Virol. 2006, 16, 37-48. [CrossRef]

12. Beaucourt, S.; Vignuzzi, M. Ribavirin: A drug active against many viruses with multiple effects on virus replication and propagation. Molecular basis of ribavirin resistance. Curr. Opin. Virol. 2014, 8, 10-15. [CrossRef]

13. Kautz, T.F.; Forrester, N.L. RNA virus fidelity mutants: A useful tool for evolutionary biology or a complex challenge? Viruses 2018, 10, 600. [CrossRef]

14. Levi, L.I.; Gnädig, N.F.; Beaucourt, S.; McPherson, M.J.; Baron, B.; Arnold, J.J.; Vignuzzi, M. Fidelity Variants of RNA Dependent RNA polymerases uncover an indirect, mutagenic activity of amiloride compounds. PLoS Pathog. 2010, 6, e1001163. [CrossRef] [PubMed]

15. Arias, A.; de Ávila, A.I.; Sanz-Ramos, M.; Agudo, R.; Escarmís, C.; Domingo, E. Molecular dissection of a viral quasispecies under mutagenic treatment: Positive correlation between fitness loss and mutational load. J. Gen. Virol. 2013, 94, 817-830. [CrossRef] [PubMed]

16. Sadeghipour, S.; Bek, E.J.; McMinn, P.C. Ribavirin-Resistant Mutants of Human Enterovirus 71 Express a High Replication Fidelity Phenotype during Growth in Cell Culture. J. Virol. 2013, 87, 1759-1769. [CrossRef]

17. Zeng, J.; Wang, H.; Xie, X.; Yang, D.; Zhou, G.; Yu, L. An increased replication fidelity mutant of foot-and-mouth disease virus retains fitness in vitro and virulence in vivo. Antiviral Res. 2013, 100, 1-7. [CrossRef] [PubMed]

18. Gnädig, N.F.; Beaucourt, S.; Campagnola, G.; Bordería, A.V.; Sanz-Ramos, M.; Gong, P.; Blanc, H.; Peersen, O.B.; Vignuzzi, M. Coxsackievirus B3 mutator strains are attenuated in vivo. Proc. Natl. Acad. Sci. USA 2012, 109, E2294-E2303. [CrossRef] [PubMed]

19. Xie, X.; Wang, H.; Zeng, J.; Li, C.; Zhou, G.; Yang, D.; Yu, L. Foot-and-mouth disease virus low-fidelity polymerase mutants are attenuated. Arch. Virol. 2014, 159, 2641-2650. [CrossRef]

20. Rozen-Gagnon, K.; Stapleford, K.A.; Mongelli, V.; Blanc, H.; Failloux, A.B.; Saleh, M.C.; Vignuzzi, M. Alphavirus Mutator Variants Present Host-Specific Defects and Attenuation in Mammalian and Insect Models. PLoS Pathog. 2014, 10, e1003877. [CrossRef]

21. Kautz, T.F.; Guerbois, M.; Khanipov, K.; Patterson, E.I.; Langsjoen, R.M.; Yun, R.; Warmbrod, K.L.; Fofanov, Y.; Weaver, S.C.; Forrester, N.L. Low-fidelity Venezuelan equine encephalitis virus polymerase mutants to improve live-attenuated vaccine safety and efficacy. Virus Evol. 2018, 4, vey004. [CrossRef]

22. Crotty, S.; Cameron, C.E.; Andino, R. RNA virus error catastrophe: Direct molecular test by using ribavirin. Proc. Natl. Acad. Sci. USA 2001, 98, 6895-6900. [CrossRef]

23. Galli, A.; Mens, H.; Gottwein, J.M.; Gerstoft, J.; Bukh, J. Antiviral Effect of Ribavirin against HCV Associated with Increased Frequency of G-To-A and C-To-U Transitions in Infectious Cell Culture Model. Sci. Rep. 2018, 8, 4619. [CrossRef]

24. Young, K.C.; Lindsay, K.L.; Lee, K.J.; Liu, W.C.; He, J.W.; Milstein, S.L.; Lai, M.M.C. Identification of a ribavirin-resistant NS5B mutation of hepatitis $C$ virus during ribavirin monotherapy. Hepatology 2003, 38, 869-878. [CrossRef] [PubMed]

25. Lutchman, G.; Danehower, S.; Song, B.C.; Liang, T.J.; Hoofnagle, J.H.; Thomson, M.; Ghany, M.G. Mutation Rate of the Hepatitis C Virus NS5B in Patients Undergoing Treatment With Ribavirin Monotherapy. Gastroenterology 2007, 132, 1757-1766. [CrossRef]

26. Hamano, K.; Sakamoto, N.; Enomoto, N.; Izumi, N.; Asahina, Y.; Kurosaki, M.; Ueda, E.; Tanabe, Y.; Maekawa, S.; Itakura, J.; et al. Mutations in the NS5B region of the hepatitis $C$ virus genome correlate with clinical outcomes of interferon-alpha plus ribavirin combination therapy. J. Gastroenterol. Hepatol. 2005, 20, 1401-1409. [CrossRef]

27. Lhomme, S.; Kamar, N.; Nicot, F.; Ducos, J.; Bismuth, M.; Garrigue, V.; Petitjean-Lecherbonnier, J.; Ollivier, I.; Alessandri-Gradt, E.; Goria, O.; et al. Mutation in the hepatitis E virus polymerase and outcome of ribavirin therapy. Antimicrob. Agents Chemother. 2016, 60, 1608-1614. [CrossRef]

28. McCammon, J.R.; Riesser, V.W. Effects of ribavirin on BHK-21 cells acutely or persistently infected with mumps virus. Antimicrob. Agents Chemother. 1979, 15, 356-360. [CrossRef] 
29. Shigeta, S.; Mori, S.; Baba, M.; Ito, M.; Honzumi, K.E.N.; Nakamura, K.; Oshitani, H.; Numazaki, Y.; Matsuda, A.; Obara, T.; et al. Antiviral Activities of Ribavirin, 5-Ethynyl-1-3-D- Several Ortho- and Paramyxoviruses. Microbiology 1992, 36, $435-439$.

30. Le Goffic, R.; Mouchel, T.; Ruffault, A.; Patard, J.-J.; Jégou, B.; Samson, M. Mumps Virus Decreases Testosterone Production and Gamma Interferon-Induced Protein 10 Secretion by Human Leydig Cells. J. Virol. 2003, 77, 3297-3300. [CrossRef] [PubMed]

31. Ivancic, J.; Forcic, D.; Gulija, T.K.; Zgorelec, R.; Repalust, L.; Baricevic, M.; Mesko-Prejac, M.; Mazuran, R. Genetic characterization of a mumps virus isolate during passaging in the amniotic cavity of embryonated chicken eggs. Virus Res. 2004, 99, 121-129. [CrossRef] [PubMed]

32. Forcic, D.; Košutić-Gulija, T.; Šantak, M.; Jug, R.; Ivancic-Jelecki, J.; Markusic, M.; Mažuran, R. Comparisons of mumps virus potency estimates obtained by 50\% cell culture infective dose assay and plaque assay. Vaccine 2010, 28, 1887-1892. [CrossRef] [PubMed]

33. Langmead, B.; Salzberg, S.L. Fast gapped-read alignment with Bowtie. Nat. Methods 2012, 9, 357-359. [CrossRef]

34. Li, H.; Handsaker, B.; Wysoker, A.; Fennell, T.; Ruan, J.; Homer, N.; Marth, G.; Abecasis, G.; Durbin, R. The Sequence Alignment/Map format and SAMtools. Bioinformatics 2009, 25, 2078-2079. [CrossRef]

35. Yang, X.; Charlebois, P.; Macalalad, A.; Henn, M.R.; Zody, M.C. V-Phaser 2: Variant inference for viral populations. BMC Genom. 2013, 14, 674. [CrossRef]

36. Slovic, A.; Kosutic Gulija, T.; Forcic, D.; Šantak, M.; Jagusic, M.; Jurkovic, M.; Pali, D.; Ivancic-Jelecki, J. Population variability generated during rescue process and passaging of recombinant mumps viruses. Viruses 2021. [CrossRef]

37. Zhao, L.; Illingworth, C.J.R. Measurements of intrahost viral diversity require an unbiased diversity metric. Virus Evol. 2019, 5, vey041. [CrossRef]

38. Šantak, M.; Markušić, M.; Balija, M.L.; Kopač, S.K.; Jug, R.; Örvell, C.; Tomac, J.; Forčić, D. Accumulation of defective interfering viral particles in only a few passages in Vero cells attenuates mumps virus neurovirulence. Microbes Infect. 2015, 17, 228-236. [CrossRef]

39. Crotty, S.; Maag, D.; Arnold, J.J.; Zhong, W.; Lau, J.Y.N.; Hong, Z.; Andino, R.; Cameron, C.E. The broad-spectrum antiviral ribonucleoside ribavirin is an RNA virus mutagen. Nat. Med. 2000, 6, 1375-1379. [CrossRef]

40. Airaksinen, A.; Pariente, N.; Menéndez-Arias, L.; Domingo, E. Curing of foot-and-mouth disease virus from persistently infected cells by ribavirin involves enhanced mutagenesis. Virology 2003, 311, 339-349. [CrossRef]

41. Vignuzzi, M.; Stone, J.K.; Andino, R. Ribavirin and lethal mutagenesis of poliovirus: Molecular mechanisms, resistance and biological implications. Virus Res. 2005, 107, 173-181. [CrossRef]

42. Moreno, H.; Gallego, I.; Sevilla, N.; de la Torre, J.C.; Domingo, E.; Martin, V. Ribavirin Can Be Mutagenic for Arenaviruses. J. Virol. 2011, 85, 7246-7255. [CrossRef]

43. Cao, D.; Gao, Y.; Roesler, C.; Rice, S.; D’Cunha, P.; Zhuang, L.; Slack, J.; Domke, M.; Antonova, A.; Romanelli, S.; et al. Cryo-EM structure of the respiratory syncytial virus RNA polymerase. Nat. Commun. 2020, 11, 368. [CrossRef]

44. Shah, N.R.; Sunderland, A.; Grdzelishvili, V.Z. Cell type mediated resistance of vesicular stomatitis virus and sendai virus to ribavirin. PLoS ONE 2010, 5, e11265. [CrossRef] [PubMed]

45. Beaucourt, S.; Bordería, A.V.; Coffey, L.L.; Gnädig, N.F.; Sanz-Ramos, M.; Beeharry, Y.; Vignuzzi, M. Isolation of fidelity variants of RNA viruses and characterization of virus mutation frequency. J. Vis. Exp. 2011, 52, e2953. [CrossRef] [PubMed]

46. Leyssen, P.; Balzarini, J.; De Clercq, E.; Neyts, J. The Predominant Mechanism by Which Ribavirin Exerts Its Antiviral Activity In Vitro against Flaviviruses and Paramyxoviruses Is Mediated by Inhibition of IMP Dehydrogenase. J. Virol. 2005, 79, 1943-1947. [CrossRef] [PubMed]

47. Lo, M.K.; Jordan, R.; Arvey, A.; Sudhamsu, J.; Shrivastava-Ranjan, P.; Hotard, A.L.; Flint, M.; McMullan, L.K.; Siegel, D.; Clarke, M.O.; et al. GS-5734 and its parent nucleoside analog inhibit Filo-, Pneumo-, and Paramyxoviruses. Sci. Rep. 2017, 7, 43395. [CrossRef]

48. Lawson, B.; Suppiah, S.; Rota, P.A.; Hickman, C.J.; Latner, D.R. In vitro inhibition of mumps virus replication by favipiravir (T-705). Antiviral Res. 2020, 180, 104849. [CrossRef]

49. Hotard, A.L.; He, B.; Nichol, S.T.; Spiropoulou, C.F.; Lo, M.K. 4'-Azidocytidine (R1479) inhibits henipaviruses and other paramyxoviruses with high potency. Antiviral Res. 2017, 144, 147-152. [CrossRef]

50. Kanra, G.; Isik, P.; Kara, A.; Cengiz, A.B.; Seçmeer, G.; Ceyhan, M. Complementary findings in clinical and epidemiologic features of mumps and mumps meningoencephalitis in children without mumps vaccination. Pediatr. Int. 2004, 46, 663-668. [CrossRef] [PubMed]

51. López-Perea, N.; Masa-Calles, J.; Torres de Mier, M. de V.; Fernández-García, A.; Echevarría, J.E.; De Ory, F.; Martínez de Aragón, M.V. Shift within age-groups of mumps incidence, hospitalizations and severe complications in a highly vaccinated population. Spain, 1998-2014. Vaccine 2017, 35, 4339-4345. [CrossRef] [PubMed]

52. Watanabe, M.; Suyama, K.; Hashimoto, K.; Sato, M.; Ohara, S.; Abe, Y.; Kawasaki, Y.; Yamaguchi, S.; Saijo, M.; Hosoya, M. Mumps virus-associated acute encephalopathy: Case report and review of the literature. J. Child. Neurol. 2013, 28, 243-245. [CrossRef] [PubMed]

53. Rehani, V.; Mahto, S.; Sheoran, A.; Singh, A.; Verma, P.; Kaushik, K. Post-mumps acute disseminated encephalomyelitis in an adolescent. J. Fam. Med. Prim. Care 2019, 8, 2533-2535. [CrossRef] 